\title{
1. Family and institutional contexts: an integrated view to advance family business research
}

\section{Giorgia Maria D'Allura}

\section{INTRODUCTION}

In family business, the presence of the family in the property and/or in the governance and/or management is largely recognized. According to a nascent literature (Backman and Palmberg, 2015), the presence of family businesses influences the institutional context in which they operate. Furthermore, from an institutional perspective, it can be seen that a family business constitutes a privileged vantage point for observation of the relationship between business and institutional context (Aparicio et al., 2017), as two institutions evolve under the reciprocal influence: the family and business.

The family is mainly the object of study of sociologists, who investigate the formal and informal conditions that govern the relationships between the members (parents, siblings, relatives) and analyze changes over time in response to the institutional context (marriages, de facto unions, separations).

The business is studied by management scholars, who investigate its organizational and strategic dynamics in response to the institutional context (relations with banks, rules and regulations, economic measures).

Traditionally, in the literature, study has focused on how the family and the business constitute two complex systems that interact, with a consequent reciprocal conditioning, although they are different in nature, objectives and logic (Astrachan et al., 2002; Lansberg, 1983; Tagiuri and Davis, 1996). The family, through the contribution of human and financial resources, aims to support and assist its members, while the business has as its objective the sale of products or services for the remuneration of production factors (Bertrand and Schoar, 2006). Although the family is driven by emotional logic and the business by economic logic, both share common principles such as continuity, union and creation of value. 
Traditionally neglected, the asset aspect is of crucial importance, since the entrepreneur's assets merge with the business and the family and include not only capital but also people, products and responsibilities (Astrachan and Kolenko, 1994; Dawson and Mussolino, 2014; Zellweger and Astrachan, 2008).

If an institutional perspective is adopted, it is believed that the findings of sociologists' research on the family can, perhaps should, constitute a valid observation point aimed at understanding the implications of the ownership and governance structures, as well as policy choices (Dyer, 2003). For example, the current organization of the family described by sociologists is certainly a starting point for understanding the successor processes in the coming years. In addition, the emotional development of interpersonal relationships resulting from the new "family systems" can be a valuable starting point for predicting entrepreneurial behavior. Finally, these dynamics at the level of the family as a social unit have implications of an institutional nature, where by "institution" we mean the set of rules that guides social behavior. Thus, for example, the evolution of interpersonal dynamics involving families (de facto couples, divorces, reconstructed families) necessarily calls for researchers in the legal field to develop the system of laws and regulations in order to include these new family systems and, from an economic point of view, to devise legal instruments capable of incorporating these aspects into firm law aimed at family businesses.

Another aspect to underline is that family businesses, in addition to contributing to national competitiveness, to the exports of a country and to the creation of jobs (Anderson and Reeb, 2003; Carney et al., 2017), also take on different social roles. For example, in developing economies, it is families that are at the heart of creating new businesses, as well as creating, safeguarding and transferring wealth (Carney, 2007). Subsequently, in the mature stages of an economy, the mix between family and non-family businesses creates the conditions for real economic development by virtue of the heterogeneity of the organizational formulas that family businesses manage to guarantee (Memili et al., 2015). Finally, the role that the family and the business are able to play, with their history and their influence, in the local economy should also be stressed.

Recently, literature has addressed the crucial role of family business as an actor in regional economic development. For example, the prevalence of family businesses within a geographical area promotes cooperation by supporting the emergence and development of innovation in the long term (Block and Spiegel, 2013). The theoretical profiles to be investigated are many and interesting. The family business is an analytical context full of ideas that, rather than being investigated individually, call for a joint study. 
In this respect, Craig and Moores (2010) stress the impossibility of ignoring the relevance and peculiarity of family businesses.

The chapter, after illustrating the theoretical foundations of institutional theory, continues with a focus on the interpretation of the implications of the family as an institution within an explanation of firm behavior and results. Lastly, the framework proposed in the chapter aims to discuss the interaction of the three levels of enquiry that operate in the family business: the family, the firm and the institutional context.

\section{THEORETICAL BACKGROUND}

\section{Institutional Theory}

Institutional theory provides a theoretical framework to investigate the interactions between organizations and the institutional environment (DiMaggio, 1991; DiMaggio and Powell, 1983; Scott, 1995). Within the framework of institutional theory, an institution is defined as a collection of "cognitive, normative, and regulative structures and activities that provides stability and meaning to social behavior" (Scott, 1995, p. 33) and "the rule of the game in a society" in general (North, 1990). Further, an institutional context consists of regulatory, normative and cultural arrangements that create, support and limit economic and social activities. This definition shapes both formal and informal institutions, with the family and the firms being two of them. Regulative arrangements are formal and are imposed by authoritative actors often through explicit rules, controls and rewards (North, 1990), whereas normative and cultural ones are informal and introduce prescriptive, evaluative and obligatory dimensions into social life (DiMaggio and Powell, 1983; Granovetter, 1985). Following those concepts, institutional theorists stress the idea that, owing to the same set of restrictions in external institutional context, organizational behaviors tend to become isomorphic over time (Aldrich and Ruef, 2006; DiMaggio and Powell, 1983). Likewise, the organizations present in the context may manipulate institutional norms and traditions (Lewin et al., 1999). Accordingly, institutional theorists consider the pressure for social conformity to be an antecedent of the convergence of firm behaviors.

The seminal work on institutional theory is Meyer and Rowan (1977). Since this work, organizational analyses based on an institutional perspective have proliferated through the investigation of a wide range of phenomena: specific personnel policies (e.g. Edelman, 1992; micro-level of analysis), redefinition of organizational missions and forms (e.g. DiMaggio, 1991; meso-level of analysis) and development of domestic 
and international policies by government organizations (e.g. Zhou, 2005; macro-level of analysis). As Scott (1987) states in his work, before the introduction of institutional conceptions, organizations were considered as production systems and/or exchange systems, and their structures were seen as being shaped by their technologies, their transactions or the powerdependency relations arising from such interdependencies. Environments were perceived as task environments: as stocks of resources, sources of information, or loci of competitors and exchange partners. These views are not wrong, but they are incomplete (Scott, 1987). The institutional theorists changed these views. Their main contribution was to direct consideration to the relevance of symbolic aspects of organizations and their environments. In doing so, they made scholars reflect and advance a growing interest in a shift in research: organizations are not technical systems. Instead, they exist in an institutional environment that defines them, delimits social reality and changes over time. Following this insight from institutional theory, in this chapter I propose to bring the family, observed as institution, into the analysis and interpretation of the family business.

\section{Family as Institution}

From a sociological point of view, family is the most important and oldest of all the institutions. In all societies, it remains the core social unit and plays a key role in organizing society. Each family creates value models that interact with the surrounding environment on a daily basis (Anderson and Sabatelli, 2011; Becvar, 2013). These models are expressed through beliefs, morals, communication methods, opinions, rituals and above all cognitive schemes useful for the education of children (Barber, 1996; Bugental and Grusec, 2006). For the right psychological development of all family members and especially children, it is therefore essential to be able to distinguish the difference between good and evil, so as to be able, during adult life, to make "the right choices." The bearers of these models are precisely the parents, who as educators must transmit those values of honesty, trust, fidelity and justice to their children that are necessary for entering into constructive relationships with one's neighbor (McGoldrick and Shibusawa, 2012). Over the years, the structure of the family has changed a lot, from patriarchal models, very numerous and made up of the parents, children and grandchildren living under the same roof, to models made up only of the parents and one or two children (McCubbin et al., 1987). In patriarchal models, men worked, while women took care of the home and the upbringing of children. Currently, both parents work outside the home. Changes in family structures inevitably 
follow those of an institutional nature, and in particular those of a legal nature. For example, the most profound change in the structure of the Italian family took place with the 1974 referendum, with the definitive institution of divorce. The reconstructed family was born in that period, that is to say divorced people who marry again in the town hall or who become a de facto couple. The delay in the introduction of divorce in Italy was likely caused by the presence of the Catholic Church, which proposed the importance of marital fidelity and, coherently, condemned divorce. The Catholic view of family certainly affected the values that Italian families embodied and transmitted to future generations. Moreover, with the introduction of divorce, the family no longer relies on Catholic rules but on lay rules. Another aspect to be stressed is that of gender equality. With the increase in education, women have become increasingly aware of their rights, leading to a reduction in marriages and births. In today's society - defined as consumerism - work is considered the first objective to be pursued, and this changes the structure of the family as well as its values. It can be assumed that the current business family pursues different objectives than the families of a few decades ago. The idea behind this book is to observe the changes in the family and, therefore, the influence that this can have on the firm. The family business scholar needs to adopt this point of view as well.

\section{Bringing the family as institution into the business}

To bring the family into family business research requires both an understanding of family theory and appropriate methods for examining families. In their work, Danes et al. (2002) argue that Stafford et al.'s (1999) sustainable family business research model draws on several theoretical models and presents some promise for understanding the family dynamics associated with a family business. The model is based on family systems theory, used to theorize about and guide research on family life (Day et al., 2001; Whitchurch and Constantine, 1993). Moreover, Danes et al. (2002) state that much of what is important in measuring family capital is not easily apprehended because it is not easy to measure. Family processes are largely unseen patterns created, sustained and modified by the family. These processes include, for example, maintenance of family boundaries, creating family rules, family resource regulation and distance regulation. These underlying patterns shape family life, determine the effectiveness of a family and are hypothesized to have reciprocal relationships with processes and outcomes of family businesses. Such family process variables can be used as independent variables in a research design or they can be used as dependent variables. The challenge is to accurately measure these processes when they are largely unseen. 
Another way to introduce family into business studies is in the work of D'Allura and Erez (2009). In order to explain the implications of the family for governance and organizational performance, the authors suggest looking at family behavior inside the firm. In their model, family behavior is the independent variable predicting firm performance. The family dynamic and process are also analyzed as predictors of firm performance. To satisfy this goal, they suggest borrowing from group literature as a clear framework that may be able to describe the family dynamic and behaviors. Moreover, they consider that the relation between family and firm performance is not direct, but mediated through the group process that the family faces inside and outside the business. The family is a group and should be analyzed as a group in order to explicate the family firm performance. The family as a group involves interpersonal dynamics and processes that strongly depend on family ties. Factors such as altruism, need for harmony, commitment, family tradition and family interdependency govern family behavior inside the business. Thus, the group processes that the family performs in governing the business are embedded in the family ties. Adopting this perspective, the difference in performance between family and non-family firms is explained using family behaviors and dynamics as a group. More specifically, Marks et al.'s (2001) conceptual model conceptualizes the family characteristics as the input into the team process. According to Marks et al. (2001), interpersonal processes occur throughout both transition (mission analysis, goal specification, strategy formulation and planning) and action (monitoring progress toward goals, systems monitoring, team monitoring and backup, coordination) phases, and typically lay the foundation for the effectiveness of other processes. More specifically, the interpersonal process of the family should be considered as a governance characteristic of family firms that turns into strategic decisions and behavior. Interpersonal processes of the family are embedded in family ties and influenced by the family's need for social structure. Thus, the relationship between family ties and group process is affected by family needs and characteristics. Both family needs and characteristics shape the interpersonal process; they shape the decision process and the relationships of the family in the business. Thus, the interpersonal processes of family firms are the distinctive factors to look at in order to explain the superior performance in family businesses.

According to D'Allura and Erez (2009) the study of the family as a group, and in general the organizational behavior (OB) literature, allows us to understand how the family, in terms of structure, processes and dynamics over time, can predict the behavior and results of family businesses. Gagné et al. (2014) contributed in the same direction as D'Allura and Erez (2009), underlining how family business scholars have been 
largely overlooked in the OB literature. Adding to the contribution of D'Allura and Erez (2009), the authors stated the importance of family business as a unique context to advance organization behavior theories, and of organization behavior as a promising discipline to increase our understanding of family business. They advance our knowledge through a selective review of literature focused on the four topics of values and goals, leadership and power, trust and justice, and conflict, discussing how insights from the general theory of communal and exchange relationships open exciting avenues for research at the family business-organization behavior interface. We are still in the first stages, but the stream of research is extremely challenging and promising. In the next section, I introduce a conceptual framework in order to understand the three levels of analysis that this chapter aims to discuss.

\section{A CONCEPTUAL FRAMEWORK}

A theoretical advancement proposition for this chapter is that in the study of family business there are three levels of enquiry: family, business and institutional context. The analysis of the literature allows us to consider that it is possible to place, on the one hand, those who work to explore, in a traditional way, the role of the family in the business and, on the other hand, those who, more recently, are investigating the interrelationship between the business and the institutional context (Peng et al., 2018; Soleimanof et al., 2018). Beyond these, another aspect that needs further investigation is the family as an institution. This is the focus of this chapter. The study of the family as an institution allows us to appreciate the changes in its structure, relationships, dynamics and organization and, consequently, to predict the impact on the firm in terms of both the creation of new ones and the management of existing ones (Schillaci et al., 2005).

The family is the central nucleus in the study of family business. As described above, it is influenced by the institutional context, and this is then transferred to the firm. Adopting the lens of upper-echelon theory, the family institution is the subject that interprets the institutional context and, therefore, the rules of the business are the result of the way in which the family experiences the institutional context. Consequently, the correct interpretation of the behavior and results of the firm cannot be separated from an in-depth investigation of these aspects.

Finally, it should be noted that the social institution family absorbs the institutional context in which it finds itself, interprets its rules and regulations and creates new paths by sometimes equipping itself with its own rules, which are not necessarily in line with what is already provided 


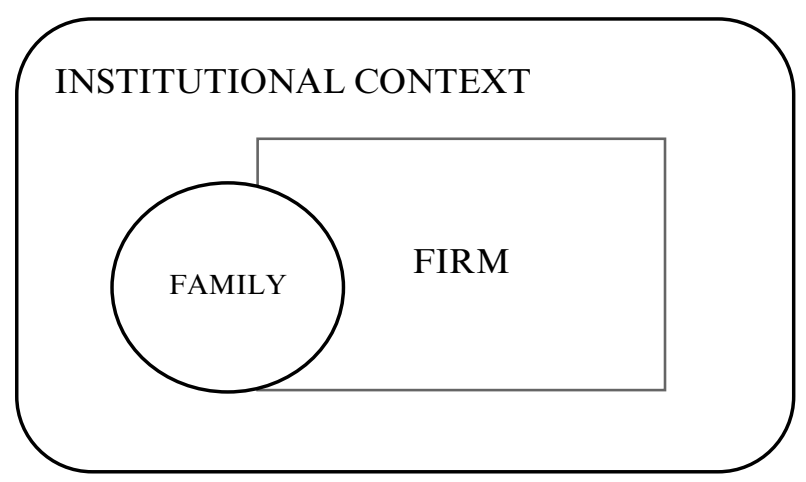

Source: Author's elaboration.

Figure 1.1 The reciprocal relationship of family, firm and institutional context

for in the context. For example, consider the spontaneous organization of de facto couples in Italy or the birth of the reconstructed family. In these cases, the family can become a promoter of the alteration of the institutional context. This is mainly the field of study of family sociologists. The family business scholar can draw on these studies in order to predict certain behaviors of the family business, especially with regard to governance choices (D’Allura, 2019).

In this respect, the submitted proposition is summarized in Figure 1.1.

Since Dyer's (2003) work, considerable progress has been made in order to investigate the family variable in a timely manner (e.g. Bertrand and Schoar, 2006). The basic idea in this work is that the firm owes its institutional structure to its upper echelons (Hambrick and Mason, 1984). It follows that the institutional structure of a family business is linked to the institutional structure of the family that owns it. Therefore, the scholar who intends to investigate the behavior of a family business is required to adopt an institutional perspective in order to understand what the rules and regulations governing the family institution are.

While, to the best of my knowledge, the study of family as institution in the family business is overlooked, the relationship between family business and contextual factors is not new in the literature. Gupta and Levenburg (2010) conducted a literature review on cross-cultural variations in family businesses. Their research yielded 16 two-nation studies and 20 multination studies, some covering seven or more nations. According to their results, the multination studies (65 percent) focused on the institutional antecedents of the family form of business and their performance effects 
(e.g. Peng and Jiang, 2010). Moreover, these studies stressed the importance of institutional variables (e.g. interventionist governments, financial market development, price controls, shareholder rights inadequacies) in supporting greater family control of businesses. The authors also found that the institutional inefficiencies are associated with greater family control of businesses but lower performance of family businesses as compared to non-family businesses. On the other side, institutional efficiencies are associated with lower family control of businesses but greater performance of family businesses as compared to non-family businesses.

In sum, institutional theory provides relevant predictions in the study of family business, specifically for multination comparisons on multiple dimensions of family business characteristics. Comparative studies are essential for enriching the family business field of knowledge. Our IFERA Research Development Workshop and this book represent a first step in shedding light on this gap. Following the previous sections of the chapter, in this section I will give some idea of further paths of research that link institutional theory and family business, bringing the family as institution into our research.

First, I consider that the family has a heterogeneous structure. Literature on family business does not always consider the family structure as a predictor or control variable in descriptive research models, because family business scholars implicitly consider that family structures tend to be homogeneous. However, researchers (especially sociologists) have described various types of family structures. For instance, Kertzer (1991, pp. 156-159) maps the following: 1) household; 2) nuclear family; 3) complex family; 4) stem family; and 5) joint family. Thus, the analysis of family firms needs to look, first of all, at the different structures of the family in order to predict issues such as succession or potential resources going from the family to the firm. In this context, Leaptrott (2005) stated that identification of the relationships between the structural configuration of the family and both the origin of various business resources and the distribution of the income or loss of the family business can result in a detailed structural description of a family business. Accordingly, I consider that a better understanding of how this structural configuration can affect family business performance under various rates of change in combinations of tasks requires more investigation. Recently, Arregle et al. (2019) introduced a new perspective for research on family firms' internationalization that is based on context and has critical importance for understanding family firms' strategies. Specifically, the authors examine the relationships of family structures, developed by Emmanuel Todd in social anthropology, to family firms' internationalization. Further studies of how institutional context influences the individual structural elements in the process of the 
adaptation over time to the institutional context will improve our understanding of the interplay between family and institutional context.

\section{Proposition 1: Family structure changes over time and influences family business performance and growth.}

Second, I consider that informal institutions, such as family norms, are embedded in a society's cultural settings. This consideration follows the works of institutional theorists focused on the intangible processes that influence the institutional process. In this regard, Scott (1995) defines an institution as a collection of "cognitive, normative, and regulative structures and activities that provide stability and meaning to social behavior" (1995, p. 33). In his view, regulative, normative and cognitive structures and activities embrace the vigor of the intangible part of the organizational results. Specifically, Scott considers that: 1) regulative force provides guidance to the members of the organization through rules, controls, rewards and sanctions; 2) normative force shapes the behavior of the organization through the social norms and values; and 3) cognitive force guides the behavior of the institution through the construction of "social identity." Accordingly, the cultural setting in which the family is located shapes the organization and behavior of the firm. Thus, the interpretation of the family firm is influenced by the cultural setting in which the family is embedded. Consequently, for instance, an Italian family business should be different than an Australian one and so on for different national contexts. Similarly, at a national level the difference between the north and the south of the state should be noticed because of the difference in historical experience, local traditions and ways to manage family life in facing the constraints of the environment.

\section{Proposition 2: $\quad$ Family norms are embedded in the cultural setting, and this has an impact on firms' behavior.}

Third, families in an institutional context tend to become isomorphic over time because they tend to adapt their behavior to the context, first of all for reputation. They may spontaneously professionalize owing to the pressures of social conformity. This idea has been formalized by DiMaggio and Powell (1983). In their work, the authors identified the nation-state as the primary modern shaper of institutional forms, given its official power. Thus, in an institutional context characterized by formal institutions, family firms tend to professionalize (Melin and Nordqvist, 2007). Therefore, an institutional context characterized by formal institutions, mostly in developed economies, is more likely to facilitate the 
professionalization of family firms (Gupta and Levenburg, 2010). In their work, Liu et al. (2012), welcoming this indication, addressed two critical questions in the family business literature: 1) What is the role of the institutional environment in affecting the choice and performance difference between family and non-family business? 2) How does the institutional environment drive the specific characteristics of family business and its performance? Specifically, they argue that institutions define family business characteristics such as ownership concentration and family management, and also affect the performance of family business.

Proposition 3: The level of family firm professionalization is related to the level of professionalization of the institutional context.

Fourth, if we shift levels of analysis, the adoption of the institutional perspective can usefully not only inquire into the ways in which institutional features shape the family as institution but also examine the determinants of institutional systems themselves departing from the family level. This is a broad and complex topic concerning which I offer here only a few general observations. Institutional theory provides insights for understanding the structure, process and phenomena in the family and in the institutional context that influence, according to our conceptual framework, the single firm. Following Friedland and Alford (1991), institutions in a social context are, at the same time, interdependent and contradictory. When institutions are contradictory, the competition for supremacy arises. The central logic of institutions is to deliver norms and rules to regulate life in a society. In this regard, I consider that family firms can be considered to be an opportunity to extend positive family relationships to the economy of a state. Accordingly, the interplay between family and institutional context is a key determinant that supports the extension of family (positive) relationships to the business. At the policy level, the idea - before helping the family firm - is to help the family wellness quality as institution.

Proposition 4: The interplay between family and institutional context is circular and shapes the family business.

\section{CONCLUSIONS}

The examination of family firms' interactions with institutional contexts has been a major research stream within family business scholarship (for a recent review see Soleimanof et al., 2018). The relevance of institutional theory to family business research has been developed by considering some 
of the broad questions examined by institutional theorists: how formal or informal institutions influence family firms and, on the contrary, how family firms influence formal or informal institutions. In this chapter, my focus was different. The aim was to understand how institutional theory can grasp the role of the family as institution inside the firm. My idea is that institutional theory should be used in order to develop a theory of family firms taking into consideration the different levels of interaction among three institutions: the family, the firm and the actor(s) in the context. Thus, I developed my thoughts, first, on family as institution and, second, on the interaction between family, firm and context. Future enquiries in this direction are, therefore, a way forward.

The chapter is a first step in the possible advancement in the study of family business through adopting the privileged perspective of the family as an institution, or investigating it by identifying the characteristics of its members, the relationships between them, and the set of rules (formal and informal) on which the interactions within and outside the firm are based. It is believed that these aspects are fundamental to understanding, for example, how the owner family interprets the context, its choices implemented in the past and, from a predictive point of view, those achievable in the near future. In line with this interpretation, the study of the innovative processes of family business has recently shown how much the family innovates following its traditions (De Massis et al., 2016). If we reread these behaviors from an institutional point of view, we observe that the family follows its rules and regulations to interpret the innovative trajectory in line with its institutional system. Recently, in the study of internationalization, too, there have been contributions that look at the family with a different focus on understanding its structural and dynamic aspects. Thus, institutional theory is promising in terms of contributing to advancing our understanding of family firm behavior and performance. Moreover, the robustness of management theories needs to be further examined in various institutional contexts (Bhagat et al., 2010), and similarly we need to extend this to the field of family business studies. Future investigation should consider the different level of analysis that institutional theory explains.

\section{REFERENCES}

Aldrich, H.E. and Ruef, M. (2006). The Evolutionary Approach: Organizations Evolving, 2nd edn. Thousand Oaks, CA: Sage, pp. 16-33.

Anderson, R.C. and Reeb, D.M. (2003). Founding-family ownership and firm performance: Evidence from the S\&P 500. Journal of Finance, 58, 1301-1328. 
Anderson, S.A. and Sabatelli, R.M. (2011). Family Interaction: A Multigenerational Developmental Perspective, 5th edn. Boston, MA: Pearson.

Aparicio, G., Basco, R., Iturralde, T. and Maseda, A. (2017). An exploratory study of firm goals in the context of family firms: An institutional logics perspective. Journal of Family Business Strategy, 8(3), 157-169.

Arregle, J.L., Hitt, M.A. and Mari, I. (2019). A missing link in family firms' internationalization research: Family structures. Journal of International Business Studies, 50(5), 809-825.

Astrachan, J.H. and Kolenko, T.A. (1994). A neglected factor explaining family business success: Human resource practices. Family Business Review, 7(3), 251-262.

Astrachan, J.H., Klein, S.B. and Smyrnios, K.X. (2002). The F-PEC Scale of Family Influence: A proposal for solving the family business definition problem. Family Business Review, 15(1), 45-58.

Backman, M. and Palmberg, J. (2015). Contextualizing small family firms: How does the urban-rural context affect firm employment growth? Journal of Family Business Strategy, 6, 247-258.

Barber, B.K. (1996). Parental psychological control: Revisiting a neglected construct. Child Development, 67, 3296-3319.

Becvar, D.S. (Ed.). (2013). Handbook of Family Resilience. New York: Springer.

Bertrand, M. and Schoar, A. (2006). The role of family in family firms. Journal of Economic Perspectives, 20(2), 73-96.

Bhagat, R.S., McDevitt, A.S. and McDevitt, I. (2010). On improving the robustness of Asian management theories: Theoretical anchors in the era of globalization. Asia Pacific Journal of Management, 27(2), 179-192.

Block, J.H. and Spiegel, F. (2013). Family firm density and regional innovation output: An exploratory analysis. Journal of Family Business Strategy, 4, 270-280.

Bugental, D.B. and Grusec, J.E. (2006). Socialization processes. In N. Eisenberg (Ed.), Handbook of Child Psychology, Vol. 3: Social, Emotional, and Personality Development, 6th edn. Hoboken, NJ: Wiley, pp. 366-428.

Carney, M. (2007). Minority family business in emerging markets: Organization forms and competitive advantage. Family Business Review, 20, 289-300.

Carney, M., Duran, P., van Essen, M. and Shapiro, D. (2017). Family firms, internationalization, and national competitiveness: Does family firm prevalence matter? Journal of Family Business Strategy, 8(3), 123-136.

Craig, J.B. and Moores, K. (2010). Championing family business issues to influence public policy: Evidence from Australia. Family Business Review, 23, 170-180.

D'Allura, G.M. (2019). The leading role of the top management team in understanding family firms: Past research and future directions. Journal of Family Business Strategy, 10(2), 87-104.

D'Allura, G. and Erez, A. (2009). The family as a group: Implications for governance and organizational performance in family firms. In M.C. Di Guardo, R. Pinna and D. Zaru (Eds.), Per lo sviluppo, la competitività e l'innovazione del sistema economico: contributo degli studi di organizzazione aziendale. Milan: FrancoAngeli, pp. 252-276.

Danes, S.M., Rueter, M.A., Kwon, H.K. and Doherty, W. (2002). Family FIRO model: An application to family business. Family Business Review, 15(1), 31-43.

Dawson, A. and Mussolino, D. (2014). Exploring what makes family firms different: Discrete or overlapping constructs in the literature? Journal of Family Business Strategy, 5(2), 169-183.

Day, R.D., Gavazzi, S. and Acock, A. (2001). Compelling family processes. In 
A. Thornton (Ed.), The Well-Being of Children and Families: Research and Data Needs. Ann Arbor: University of Michigan Press, pp. 103-126.

De Massis, A., Frattini, F., Kotlar, J., Petruzzelli, A.M. and Wright, M. (2016). Innovation through tradition: Lessons from innovative family businesses and directions for future research. Academy of Management Perspectives, 30(1), 93-116.

DiMaggio, P. (1991). Social structure, institutions, and cultural goods: The case of the US. In P. Bourdieu and J. Coleman (Eds.), Social Theory for a Changing Society. Boulder, CO: Westview Press, pp. 133-155.

DiMaggio, P.J. and Powell, W.W. (1983). The iron cage revisited: Institutional isomorphism and collective rationality in organizational fields. American Sociological Review, 48(2), 147-160.

Dyer, W.G., Jr. (2003). The family: The missing variable in organizational research. Entrepreneurship Theory and Practice, 27(4), 401-416.

Edelman, L.B. (1992). Legal ambiguity and symbolic structures: Organizational mediation of civil rights law. American Journal of Sociology, 97(6), 1531-1576.

Friedland, R. and Alford, R.R. (1991). Bringing society back in: Symbols, practices and institutional contradictions. In W.W. Powell and P.J. DiMaggio (Eds.), The New Institutionalism in Organizational Analysis. Chicago: University of Chicago Press, pp. 232-267.

Gagné, M., Sharma, P. and De Massis, A. (2014). The study of organizational behaviour in family business. European Journal of Work and Organizational Psychology, 23(5), 643-656.

Granovetter, M. (1985). Economic action and social structure: The problem of embeddedness. American Journal of Sociology, 91(3), 481-510.

Gupta, V. and Levenburg, N. (2010). A thematic analysis of cultural variations in family businesses: The CASE project. Family Business Review, 23(2), 155-169.

Hambrick, D.C. and Mason, P.A. (1984). Upper echelons: The organization as a reflection of its top managers. Academy of Management Review, 9(2), 193-206.

Kertzer, D.I. (1991). Household history and sociological theory. Annual Review of Sociology, 17(1), 155-179.

Lansberg, I.S. (1983). Managing human resources in family firms: The problem of institutional overlap. Organizational Dynamics, 12(1), 39-46.

Leaptrott, J. (2005). An institutional theory view of the family business. Family Business Review, 18(3), 215-228.

Lewin, A.Y., Long, C.P. and Carroll, T.N. (1999). The coevolution of new organizational forms. Organization Science, 10(5), 535-550.

Liu, W., Yang, H. and Zhang, G. (2012). Does family business excel in firm performance? An institution-based view. Asia Pacific Journal of Management, 29(4), 965-987.

Marks, M.A., Mathieu, J.E. and Zaccaro, S.J. (2001). A temporally based framework and taxonomy of team processes. Academy of Management Review, 26(3), 356-376.

McCubbin, H.I., Thompson, A., Pirner, P. and McCubbin, M.A. (1987). Family Types and Strengths: A Life Cycle and Ecological Perspective. Edina, MI: Burgess International.

McGoldrick, M. and Shibusawa, T. (2012). The family life cycle. In F. Walsh (Ed.), Normal Family Processes: Growing Diversity and Complexity, 4th edn. New York: Guilford, pp. 375-398.

Melin, L. and Nordqvist, M. (2007). The reflexive dynamics of institutionalization: The case of the family business. Strategic Organization, 5(3), 321-333. 
Memili, E., Fang, H., Chrisman, J.J. and De Massis, A. (2015). The impact of smalland medium-sized family firms on economic growth. Small Business Economics, 45, 771-785.

Meyer, J.W. and Rowan, B. (1977). Institutionalized organizations: Formal structure as myth and ceremony. American Journal of Sociology, 83(2), 340-363.

North, D.C. (1990). A transaction cost theory of politics. Journal of Theoretical Politics, 2(4), 355-367.

Peng, M.W. and Jiang, Y. (2010). Institutions behind family ownership and control in large firms. Journal of Management Studies, 47(2), 253-273.

Peng, M.W., Sun, W., Vlas, C., Minichilli, A. and Corbetta, G. (2018). An institution-based view of large family firms: A recap and overview. Entrepreneurship Theory and Practice, 42(2), 187-205.

Schillaci, C.E., Faraci, R. and D’Allura, G.M. (2005). Il ruolo della famiglia nel fenomeno dell'apertura delle imprese familiari italiane. Piccola Impresa, 3, 55-71.

Scott, W.R. (1987). The adolescence of institutional theory. Administrative Science Quarterly, 32(4), 493-511.

Scott, W.R. (1995). Institutions and Organizations. London: Sage.

Soleimanof, S., Rutherford, M.W. and Webb, J.W. (2018). The intersection of family firms and institutional contexts: A review and agenda for future research. Family Business Review, 31(1), 32-53.

Stafford, K., Duncan, K.A., Dane, S. and Winter, M. (1999). A research model of sustainable family businesses. Family Business Review, 12(3), 197-208.

Tagiuri, R. and Davis, J. (1996). Bivalent attributes of the family firm. Family Business Review, 9(2), 199-208.

Whitchurch, G.G. and Constantine, L.L. (1993). Systems theory. In P.G. Boss, W.J. Dougherty, R. LaRossa, W.R. Schumm and S.K. Steinmetz (Eds.), Sourcebook of Family Theory and Methods: A Contextual Approach. New York: Plenum, pp. 325-352.

Zellweger, T.M. and Astrachan, J.H. (2008). On the emotional value of owning a firm. Family Business Review, 21(4), 347-363.

Zhou, M. (2005). Ethnicity as social capital: Community-based institutions and embedded networks of social relations. In G.C. Loury, T. Modood and S.M. Teles (Eds.), Ethnicity, Social Mobility, and Public Policy: Comparing the USA and UK. Cambridge: Cambridge University Press, pp. 131-159. 